\title{
The origin of large varioles in flow-banded pillow lava from the Hooggenoeg Complex, Barberton Greenstone Belt, South Africa
}

\author{
Nils Rune Sandstå • Brian Robins · Harald Furnes • \\ Maarten de Wit
}

Received: 1 June 2010/ Accepted: 24 November 2010/Published online: 14 December 2010

(C) The Author(s) 2010. This article is published with open access at Springerlink.com

\begin{abstract}
Exceptionally well-preserved pillowed and massive phenocryst-free metabasaltic lava flows in the uppermost part of the Palaeoarchaean Hooggenoeg Complex of the Barberton Greenstone Belt exhibit both flow banding and large leucocratic varioles. The flow banding is defined by blebs and bands of pale and dark green metabasalt and was the result of mingling of two types of basalt (Robins et al. in Bull Volcanol 72:579-592, 2010a). Varioles occur exclusively in the dark chlorite-, $\mathrm{MgO}$ - and $\mathrm{FeO}$-rich metabasalt. Varioles are absent in the outermost rinds of pillows and increase in both abundance and size towards the centres of pillows. In the central parts of some pillows, they impinge to form homogeneous pale patches, bands or almost homogenous cores. Individual varioles consist essentially of radially orientated or outwardly branching dendritic crystals of albite. Many varioles exhibit concentric zones and finer-grained rims. Some varioles seem to have grown around tiny vesicles and vesicles appear to have been trapped in others between a
\end{abstract}

Communicated by T. L. Grove.

N. R. Sandstå

Norwegian Petroleum Directorate,

Post Box 600, 4003 Stavanger, Norway

B. Robins $(\bowtie)$

Department of Earth Science, University of Bergen,

5007 Bergen, Norway

e-mail: brian.robins@geo.uib.no

H. Furnes

Department of Earth Science and Centre for Geobiology,

University of Bergen, 5007 Bergen, Norway

M. de Wit

AEON and Department of Geological Sciences,

University of Cape Town, Rondebosch 7700, South Africa core and a finer-grained rim. The matrix surrounding the ocelli contains acicular pseudomorphs of actinolite and chlorite after chain-like, skeletal Ca-rich pyroxenes that are partly overgrown by the margins of varioles. Varioles are enriched in the chemical constituents of feldspar but contain concentrations of immobile $\mathrm{TiO}_{2}, \mathrm{Cr}, \mathrm{Zr}$ and REE that are similar to the host metabasalts. The shape, distribution, texture and composition of the varioles exclude liquid immiscibility and support an origin by spherulitic crystallisation of plagioclase from severely undercooled basalt melt and glass. Nucleation of plagioclase was strongly inhibited and took place on vesicles, on the bases of drainage cavities and along early fractures. Eruption in deep water and retention of relatively high concentrations of volatiles in the melt may be the principal cause of spherulitic crystallisation in the interiors of pillows rather than only in their margins as in younger submarine flows.

Keywords Varioles - Pillow lava P Plagioclase spherulites - Archaean lava - Barberton - Greenstone Belt . Hooggenoeg

\section{Introduction}

Varioles are leucocratic globular objects, $\mathrm{mm}$ to $\mathrm{cm}$ in diameter, that are conspicuous within certain basaltic lavas, particularly in tachylitic pillow margins (see Phillips (1973) for a review of nomenclature). Large varioles have been referred to as ocelli by some authors but generally have a radial rather than a tangential internal orientation of crystals. Their origin is commonly masked by low-temperature alteration, metamorphic recrystallisation or deformation and is controversial. Large varioles appear to be particularly common in Archaean volcanic rocks 
(Gelinas et al. 1976) and hence may have implications for magma generation in the early mantle, but they are not restricted to ancient basalts as they have been reported in a lower Palaeozoic ophiolite (Upadhyay 1982) as well as Cretaceous pillow lava from the Caribbean (Kerr et al. 1996) and Ontong Java volcanic plateaux (Shipboard Scientific Party 2001). Varioles were considered by Viljoen and Viljoen (1969) to be characteristic of basaltic komatiites in the Barberton Greenstone Belt. Ferguson and Currie (1972) interpreted these structures as due to liquid immiscibility. Immiscibility in tholeiitic magma was also proposed by Gelinas et al. (1976) as the origin of similar structures in the Abitibi Greenstone Belt. The differences in major-element concentrations in the globules and the surrounding metabasalts were claimed to support this idea. Fowler et al. $(1987,2002)$ re-examined the occurrences of varioles in the Abitibi Greenstone Belt and they concluded that most were the result of spherulitic crystallisation in highly undercooled melts but that some may be the result of magma mixing. Varioles in strongly deformed and metamorphosed pillow lava within the Isua Greenstone Belt have recently also been attributed to mingling of mafic and crustal felsic magmas (Appel et al. 2009). Varioles in early Proterozoic ferropicritic pillows and dikes in the Pechenga Group of the Kola Peninsula appear to overprint fractures and were attributed to secondary alteration of glass by Hanski (1993).

This study focuses on the origin and implications of the conspicuous and abundant leucocratic varioles that occur within flow-banded pillow and massive basaltic lava uppermost in the volcanic sequence of the Palaeoarchaean Hooggenoeg Complex (de Wit et al. in press) in the southern part of the Barberton Greenstone Belt in South Africa (Fig. 1). These volcanic rocks are extremely well preserved. They have only experienced low-grade metamorphism, lack penetrative deformation and in places are very clearly exposed due to scouring by the Komati River. Field, petrographic and geochemical data are used to test the widely different hypotheses proposed for the formation of varioles. Our observations support an origin by the spherulitic crystallisation of plagioclase from severely undercooled hydrous basalt lava erupted in deep water.

\section{Field relations}

The lavas described here occur within member H5 of Lowe and Byerly $(1999,2007)$ and section HV15 of Furnes et al. (in press) in the stratigraphically uppermost part of the $\sim 3,900$-m-thick sequence of volcanic and intrusive rocks within the Hooggenoeg Complex (de Wit et al. in press) on the eastern limb of the Onverwacht Anticline (Fig. 1). The upper $271 \mathrm{~m}$ of the sequence as developed along the
Komati River approximately $2.5 \mathrm{~km}$ upstream from the footbridge, close to the Kromdraai entrance to the Songimvelo Nature Reserve (UTM 36 J 0299430, 7125387 to $36 \mathrm{~J}$ 0298743, 7120210), consists mainly of conspicuously variolitic, flow-banded pillow lava and sparse, thin massive units (Fig. 1). Lowe and Byerly (1999) report that the sequence of variolitic lava has a regional development. The lavas in this continuous section are tilted almost to the vertical, young to the south-east, and are exposed in clean and polished surfaces, particularly between 80 and $150 \mathrm{~m}$ from the base. At the top of the section, there is a 19-mthick sheet flow with a lobate silicified and variolitic top.

The diameters of pillows in the section vary from a few $\mathrm{dm}$ to as much as $\sim 4 \mathrm{~m}$. Systematic upward decreases in the size of pillows define stratigraphic subunits. Smaller pillows have subcircular, bun shaped to distinctly flattened, bean and pedunculate cross-sections that are moulded onto underlying pillows. Sections through large pillows vary in aspect ratio from higher than they are wide to extremely elongate in the plane of the general layering, depending partly on the relative orientations of the longest axes of the tubular pillows. Cavities between pillows are occupied by hyaloclastite or filled by hydrothermal quartz and carbonate. Single or multiple flat-bottomed drainage slots (e.g. Dann and Grove 2007), now filled with quartz and carbonate, are relatively common but the radial jointing, generally developed in young, unaltered pillows, is absent. The lavas are aphyric and generally non-vesicular. Sparse, small vesicles have been noted in two thin units of variolitic pillows in the lower and upper parts of the section investigated (Fig. 1).

The pillow lavas in much of the section are conspicuously flow banded. The flow structure is defined by alternating $\mathrm{mm}$ to several $\mathrm{cm}$ thick pale green to dark greyish-green or nearly black bands. The banding is interpreted to be the result of stretching and folding during laminar flow of an inhomogeneous mixture of two compositionally different types of basalt through the tubular pillows (Robins et al. 2010a). The flow banding is generally concentric and parallel to pillow margins but in places it defines mushroomlike structures that seem to be a result of secondary, lateral lava flow due to bends in pillow tubes.

A compositionally and texturally distinctive, purplishblack variety of metabasalt has been recognised in the cores of some of the larger pillows in the section and is inferred to have refilled previously drained, hollow pillows (Robins et al. 2010b). No varioles occur in this variety of metabasalt but wide bands of impinging varioles are commonly developed in the flow-banded carapaces along the contacts with the massive cores.

The varioles are crystalline, near spherical leucocratic globules. Depending on the location of sections relative to their centres, they exhibit two or more concentric zones, 

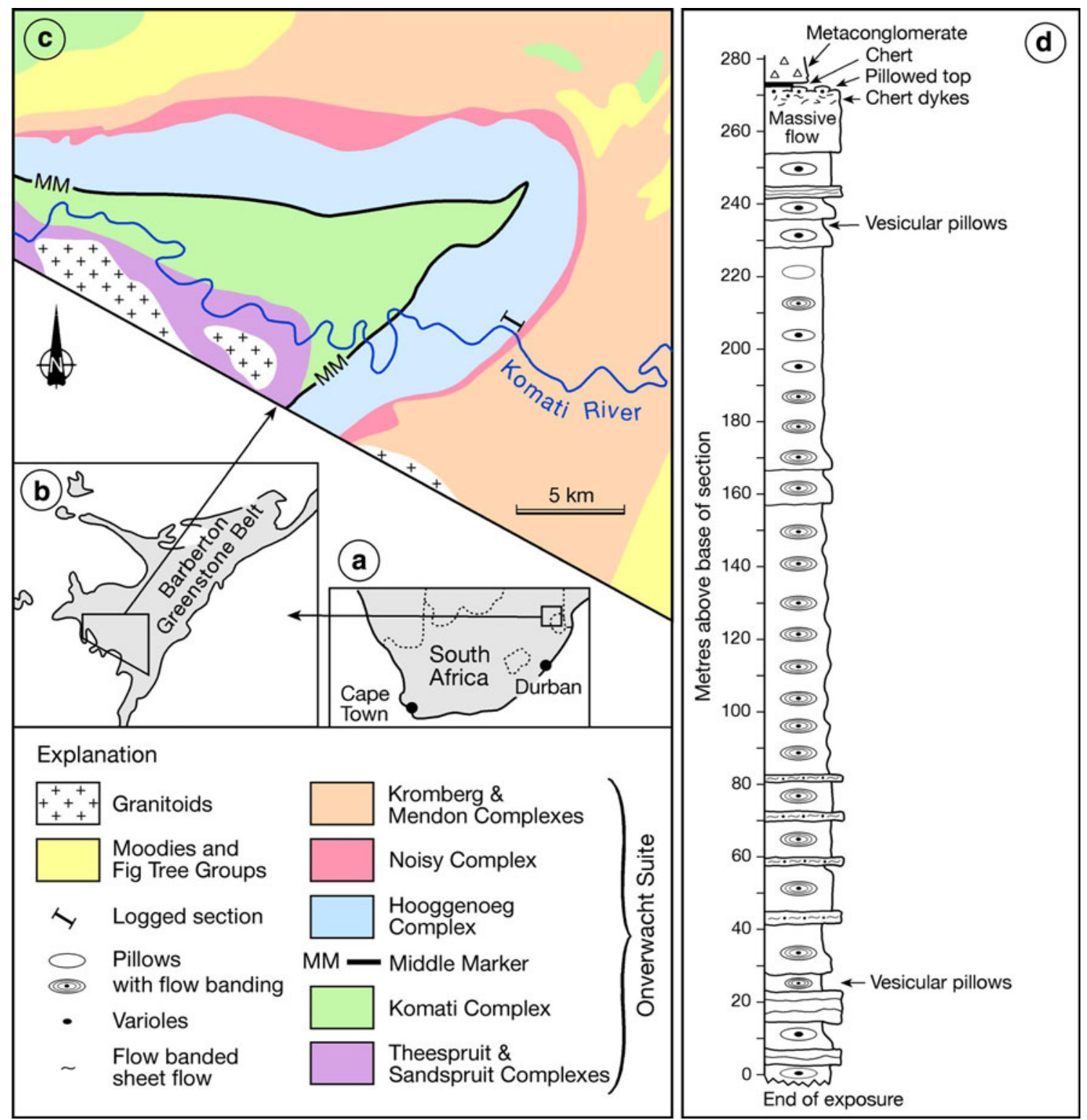

Fig. 1 a-c Simplified geological map of the southern part of the Barberton Greenstone Belt showing the location of the logged section through the uppermost part of the volcanic sequence of the Hooggenoeg Complex along the Komati River. The recently defined Noisy Complex consists of felsic volcanic, volcaniclastic and shallow intrusive rocks (de Wit et al. in press). d Stratigraphic log showing the

generally with a pale core, surrounded by a greyish-green intermediate zone and a lighter coloured rim (Fig. 2). The concentric internal zoning in individual varioles is generally conserved in groups of impinging varioles and sharp cusps invariably separate adjacent varioles (Fig. 2). This observation demonstrates conclusively that the groups are not coalescing drops of acid melt.

Varioles are generally absent in the margins of the pillows, but small varioles, $\sim 1 \mathrm{~mm}$ in diameter, appear distribution of massive metabasalt (flow banding indicated by wavy lines), pillow lava (single ovals), flow-banded pillow lava (concentric ovals) and the occurrence of leucocratic varioles (dots). The width of the stratigraphic column portrays the size of the pillows. The thin flow-banded massive units logged in the 40- to 90-m interval may be exceptionally large, elongated pillows rather than separate sheet flows

3-4 cm within pillow margins and become progressively larger inwards. Individual varioles can be as large as $4 \mathrm{~cm}$ in diameter near the cores of pillows. Commonly, varioles become more abundant towards the centres of pillows. This is particularly well displayed by variolitic pillows lacking flow banding within the lower part of the Hooggenoeg Complex as exposed in the Mtsoli River (along section HV4 of Furnes et al. in press). Here, the size and number of varioles increases rapidly from the aphanitic pillow 

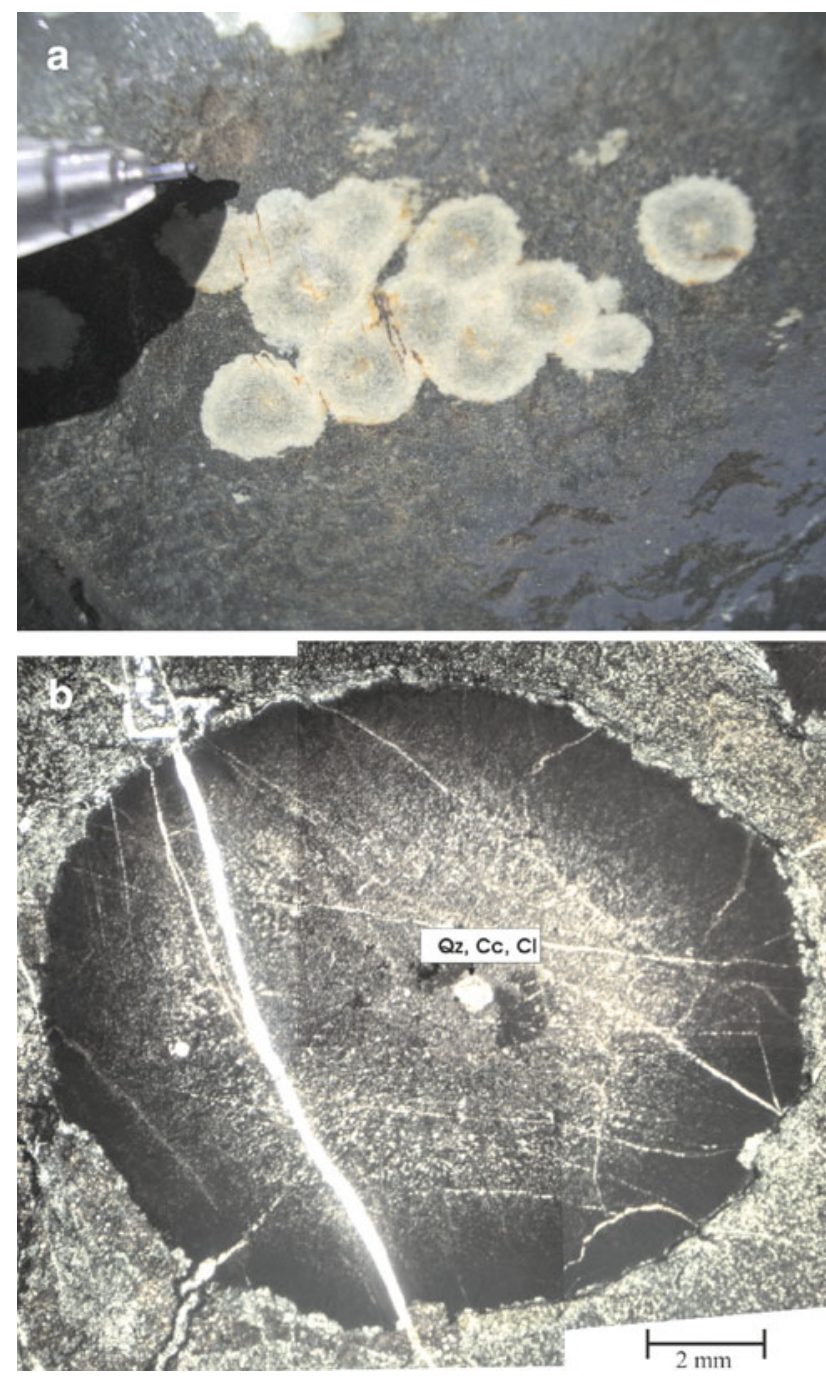

Fig. 2 a Varioles with pronounced concentric zoning. Note that the zoning exhibited by the isolated variole is conserved in the group of impinging varioles, proving that they cannot be merged drops of acid melt. b Composite transmitted-light photomicrograph of a variole with a small amygdale filled by quartz, carbonate and chlorite at its centre and a dark, finer-grained rim set in a green, chlorite-rich matrix

margins until they impinge on each other and finally merge into a massive, crystalline and pale core containing sparse and dispersed dark chlorite-rich patches (Fig. 3).

In flow-banded pillows, varioles occur exclusively in blebs, bands and veins of the darker, chlorite-rich variety of metabasalt. Dispersed blebs of dark metabasalt up to a few $\mathrm{cm}$ across commonly enclose single, centrally located varioles (Fig. 4). In veins and bands of dark metabasalt, varioles may be organised into strings or merged into discontinuous streaks. These pick out the original banding that defines a variety of patterns related to flow of inhomogeneous lava through pillows (Robins et al. 2010a). The flow banding is generally parallel to pillow margins and has a concentric structure, but certain pillows exhibit

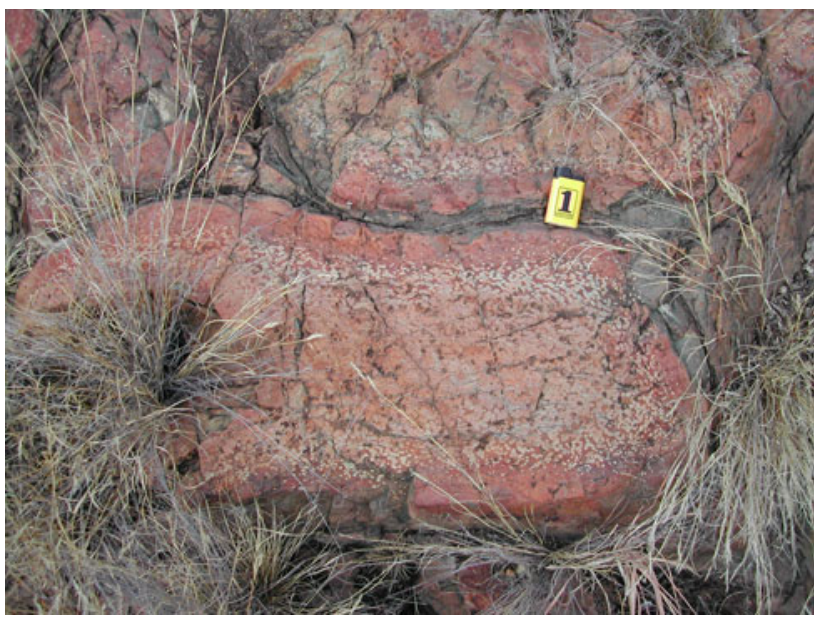

Fig. 3 Metabasaltic pillows exposed in the Mtsoli River showing an inwardly increasing abundance and size of varioles from variole-free rims to cores composed largely of impinging varioles. The photographed lava is from section HV4 through the stratigraphically lower part of the volcanic sequence in the Hooggenoeg Complex described by Furnes et al. (in press)

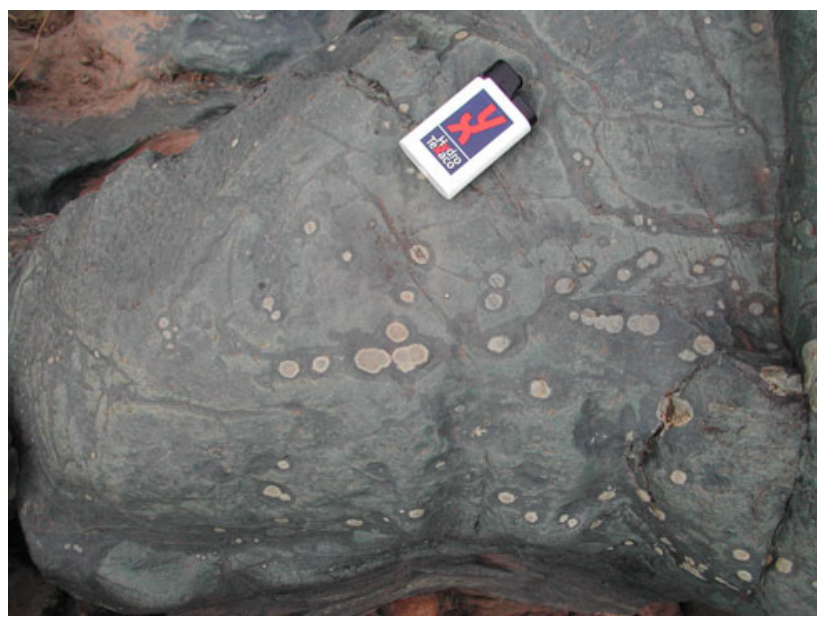

Fig. 4 Pillow with large leucocratic varioles located within blebs of dark green metabasalt dispersed within pale green metabasalt. Some almost spherical blebs contain a single variole in the middle

diapir-like internal structures that result in complex patterns defined by trains of varioles or bands of impinging varioles that in some instances bear a fanciful resemblance to a section through the two halves of human brains or even an octopus (Fig. 5).

Bands of pale green metabasalt do not contain leucocratic varioles. This variety of metabasalt contains bow tie or radial spherulites consisting of actinolite pseudomorphs after branching, frond-like plates or prismatic skeletal crystals of pyroxene as well as arrow- or mace-like pseudomorphs, probably after olivine (Robins et al. 2010a).

The volume of varioles present in typical flow-banded pillows has been estimated from digital photographs using 


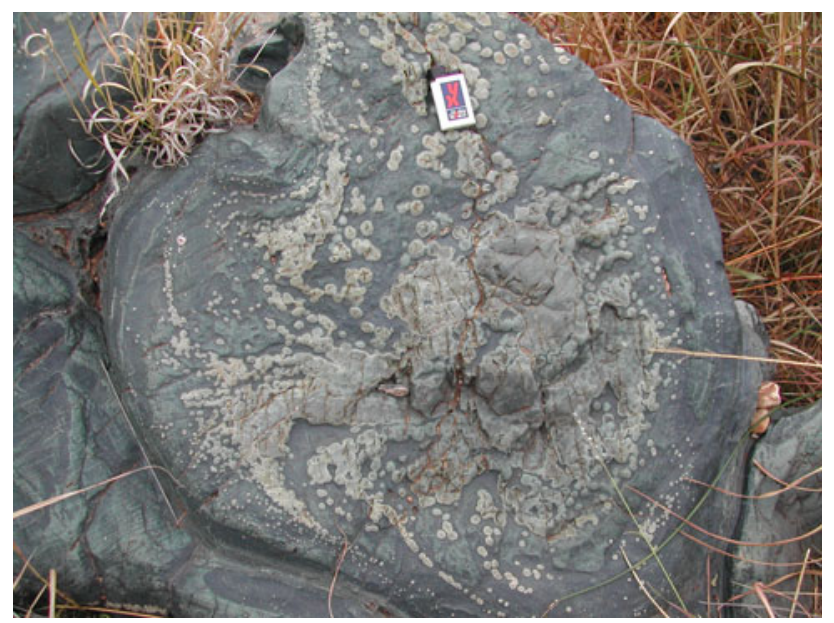

Fig. 5 Pillow with sharply demarcated core of dark variolitic metabasalt within a carapace of flow-banded, mainly pale green metabasalt. Trains and bands of impinging varioles along the faint flow banding pick out an octopus-like structure in the core due to secondary, transverse flow (Robins et al. 2010a)

an image analysis programme. Their abundance varies from $<1$ to $52 \%$, depending on the relative amounts of the pale and dark green lava types present. The amount of varioles present within the dark variety of metabasalt itself varies from 2 to $71 \%$.

Impinging varioles generally form a continuous band along the bases of drainage cavities, but not along their arched roofs (Fig. 6). A similar phenomenon is the occurrence of wide bands of partially to completely impinging varioles developed in the flow-banded carapaces surrounding the black metabasaltic cores of some larger pillows that are inferred to have originated by the later refilling of originally hollow pillows (Robins et al. 2010b).

Some horizontally elongated pillows are characterised by varioles that appear to have impinged to form bands that are orientated in a stratigraphically vertical direction, possibly along incipient cooling fractures (Fig. 7).

\section{Texture and mineralogy of varioles and their matrix}

The pillow lavas in the uppermost part of the Hooggenoeg Complex now consist exclusively of secondary assemblages of metamorphic minerals, but due to the lack of penetrative deformation, primary minerals are pseudomorphed and delicate textures are remarkably well preserved. The textures of a number of varioles and their enclosing matrices have been investigated in petrographic thin sections by optical and scanning electron microscopy and their constituent minerals identified either by their optical properties or by energy-dispersive X-ray spectrometry (EDS).
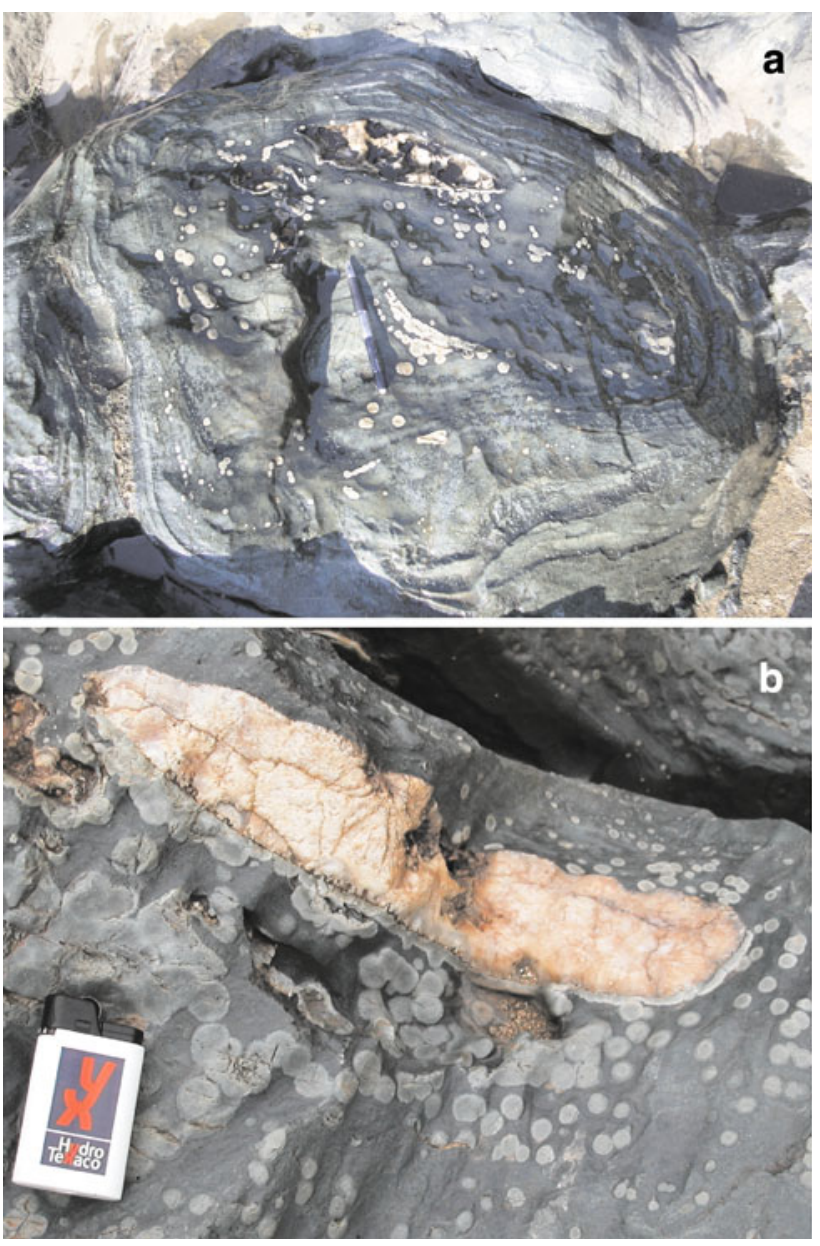

Fig. 6 a Pillow with concentric flow bands, some of which enclose trains of varioles, and a quartz-filled former drainage cavity with a domed roof. A light band of impinging varioles follows the base of the former cavity. b Close-up of a quartz-filled drain-out with impinging varioles along its base but not along the roof

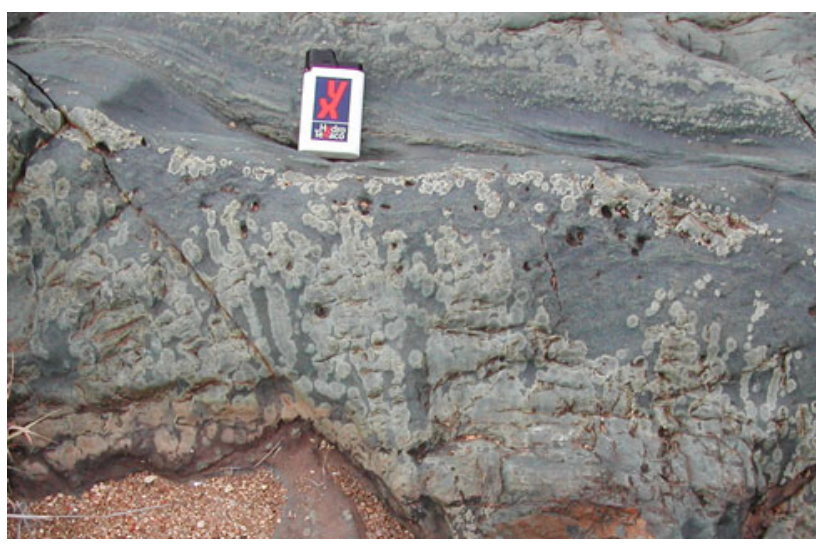

Fig. 7 The cigarette lighter rests on the upper surface of an elongated pillow with a core exhibiting vertical trains of impinging varioles that may have developed along early cooling fractures

Varioles generally comprise a narrow, very fine-grained outer zone that borders on the matrix with a sharp contact and an inner, coarser grained zone that forms the main part 


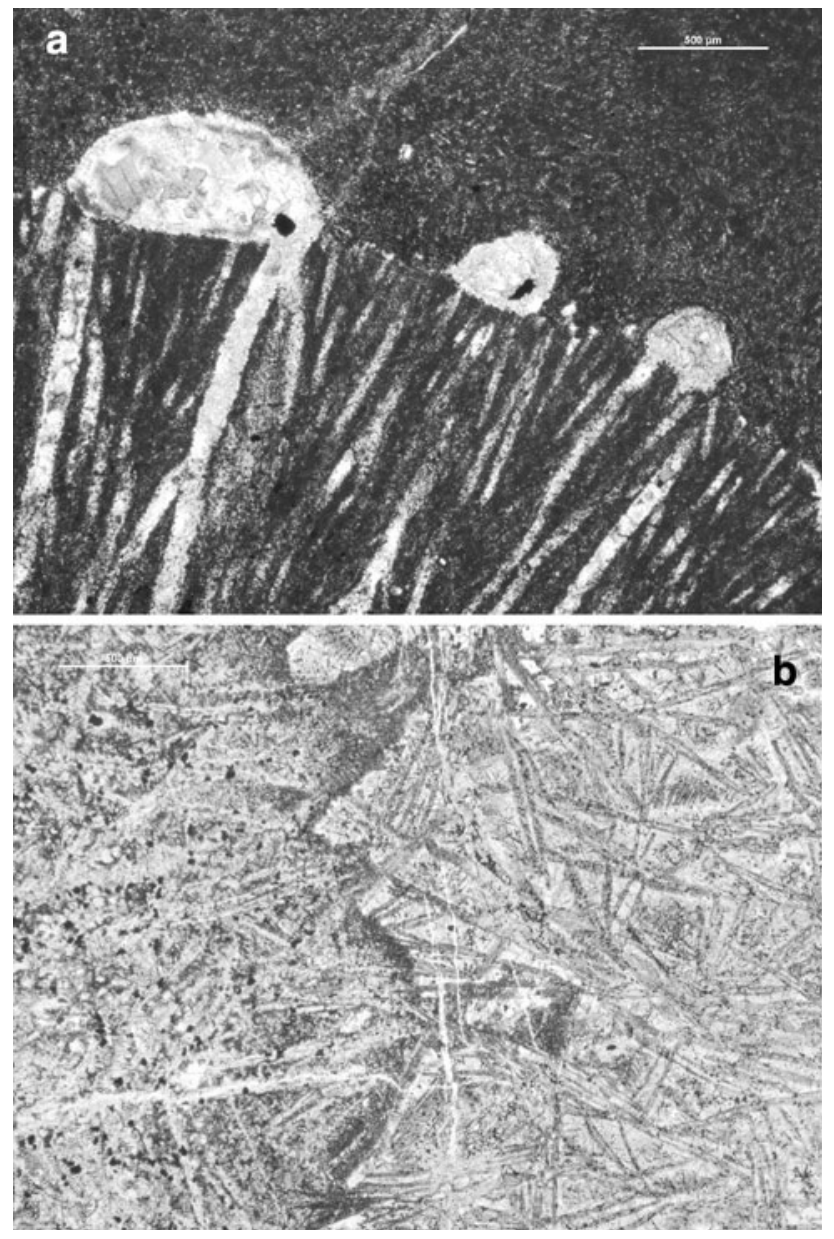

Fig. 8 a Photomicrograph of a variole consisting of radially orientated sheaves of albite (black) containing radial pipe amygdales (light) and hemispherical amygdales trapped between the core and the fine-grained margin of the variole. b Pseudomorphs of actinolite after skeletal pyroxene in the metabasaltic host to the leucocratic varioles (on the right side of the photomicrograph). The prismatic pyroxene is overgrown by and enclosed in the margin of the variole. Scale bars are $500 \mu \mathrm{m}$ long in both photomicrographs

of the varioles (Fig. 2b). Curiously, the colour and opacity of varioles in transmitted plane-polarised light is the reverse of that in exposed surfaces in the field: the outer zone is dark and in some cases nearly opaque while the inner parts of varioles are brighter. In some sections, there is an indistinct coarser grained core around a central amygdale, generally filled with calcite, quartz and a little chlorite (Fig. 2b), although these are not visible in all petrographic thin sections. The boundary between the inner and outermost zones is sharp to indistinct and in some cases is marked by small subspherical amygdales, some of which are demonstrably continuous with elongated, radial amygdales in the inner part of the variole (Fig. 8a). Around the outer margins of some varioles, there are narrow rims that consist almost exclusively of Fe-rich chlorite (chamosite).
Varioles generally have a radial internal structure and consist largely of outwardly branching prismatic or feathery crystals identified by EDS as albite and generally subordinate $\mathrm{K}-\mathrm{Na}$ feldspar, both dark coloured in transmitted light, with intervening fine-grained, optically irresolvable material consisting of albite and alkali feldspar, epidote, actinolite, chlorite, calcite and quartz or elongated areas of coarser grained quartz and calcite. The latter may be continuous with the amygdales located between the inner and outermost fine-grained zones of the varioles and are inferred to have filled microscopic radial pipe vesicles (Fig. 8a). Epidote is a common but subordinate mineral in varioles and generally forms acicular to stubby prisms much smaller than the feldspars. It occurs in largest amount in the outer, finer-grained zone of varioles and is accompanied by actinolite, chlorite, calcite and sphene.

The matrix between varioles contains abundant prismatic pseudomorphs of actinolite, probably after acicular Ca-rich pyroxene, as well as chlorite that resides in a very fine-grained and irresolvable mass, presumably the original crystalline or glassy matrix. In BSE images, the pseudomorphs have a chain-like appearance and discontinuous darker cores, suggesting that they either were originally skeletal, hollow crystals or were compositionally zoned. The actinolite pseudomorphs have random orientations or form open bow-tie and fanning spherulitic aggregates (Fig. 8b). The outermost parts of some varioles enclose similar actinolite pseudomorphs and thus appear to have overgrown acicular pyroxene. Rare, small $(<1 \mathrm{~mm})$ amygdales filled by quartz and calcite have been observed in the metabasaltic matrix around varioles.

\section{Chemical analyses of varioles and their host}

We have investigated the compositions of individual and impinging varioles as well as their host dark green metabasalt by careful collection of homogeneous specimens in the field and by isolating uniform samples using a diamond saw. The concentrations of the major and selected trace elements were determined in glass beads and powder pellets prepared from samples pulverised in an agate mill employing a Philips PW 1404 X-ray fluorescence spectrometer at the Department of Earth Science, University of Bergen. International standards and the concentrations recommended by Govindaraju (1994) were used for calibration. Rare earth element (REE) concentrations were determined using a Finnigan Element 2 inductively coupled plasma mass spectrometer (ICP-MS) housed at the Department of Earth Science, University of Bergen. Pulverised samples were digested in $\mathrm{HF}$ and $\mathrm{HNO}_{3}$ at a temperature of $163^{\circ} \mathrm{C}$ for 2 days, diluted 2,457 times in $2 \%$ $\mathrm{HNO}_{3}$ and analysed using standard techniques; $1 \mathrm{ppb}$ of 
${ }^{115}$ In was added to all solutions as an internal standard, and BCR-2a and BCR-2b were employed to monitor analytical errors.

Chemical analyses of the dark green, variolitic metabasalt, separated varioles and the associated pale green metabasalt are listed in Tables 1, 2, 3, and selected elements are plotted in the Harker diagrams presented in Fig. 9.

The dark metabasalt that hosts varioles has a generally basaltic average composition with an $\mathrm{MgO}$ content between 4.6 and $10.1 \%$ (average $7.1 \%$ ), but with relatively low $\mathrm{SiO}_{2}$ and exceptionally high concentrations of iron $\left(>16 \mathrm{wt} \% \quad \mathrm{Fe}_{2} \mathrm{O}_{3}^{(\mathrm{t})}\right.$ ). The compositional spread in the samples of dark green metabasalt is inferred to be a result of interaction with the conjugate basalt during mingling as well as during subsequent low-temperature alteration. Alteration in the metabasalts involved varying degrees of chloritisation, carbonatisation and silicification (Robins et al. 2010a). The dark green metabasalt in these particular samples appears to have lost $\mathrm{SiO}_{2}$ and gained $\mathrm{MgO}$ and $\mathrm{Fe}_{2} \mathrm{O}_{3}^{(\mathrm{t})}$, as a consequence of chloritisation. The variolefree, pale green metabasalt is higher in $\mathrm{SiO}_{2}$ and lower in $\mathrm{Al}_{2} \mathrm{O}_{3}, \mathrm{TiO}_{2}, \mathrm{MgO}, \mathrm{Fe}_{2} \mathrm{O}_{3}^{(\mathrm{t})}$ and $\mathrm{Ni}$ than the associated dark green metabasalt.

Varioles are enriched in $\mathrm{SiO}_{2}$ and $\mathrm{Na}_{2} \mathrm{O}$ and depleted in $\mathrm{Fe}_{2} \mathrm{O}_{3}^{(\mathrm{t})}$, $\mathrm{MnO}$ and $\mathrm{MgO}$ relative to the metabasalts. Presumably, the varioles have gained both $\mathrm{SiO}_{2}$ and $\mathrm{Na}_{2} \mathrm{O}$ during low-temperature replacement of the original plagioclase by albite. However, the varioles contain surprisingly high and uniform concentrations of $\mathrm{TiO}_{2}$, probably mainly contained in dispersed, fine-grained sphene, as well as relatively high $\mathrm{CaO}$ and $\mathrm{Cr}$. $\mathrm{Cr}$ and $\mathrm{Zr}$ were relatively immobile elements during alteration of the Barberton volcanic rocks (Furnes et al. in press) and have similar concentrations in the varioles and the host metabasalt. $\mathrm{P}_{2} \mathrm{O}_{5}$ also has similar, but low concentrations in both varioles and the dark green metabasalt. Two of the analysed samples consisted of impinging varioles from the central parts of pillows, and these contain more $\mathrm{MgO}$ and $\mathrm{Fe}_{2} \mathrm{O}_{3}^{(\mathrm{t})}$ than the others, although not as much as in samples of the isolated dark type of metabasalt.

REE are generally immobile during low-temperature alteration and metamorphism. They have similar concentrations in both varieties of metabasalt and exhibit rather flat, MORB-like, chondrite-normalised patterns. The varioles have REE concentrations similar to those of the metabasalts but are slightly enriched in LREE and depleted in HREE (Fig. 10).

Major- and trace-element analyses exist for a large number of samples collected through the volcanic stratigraphy of the Hooggenoeg Complex, both with and without varioles (Furnes et al. in press). Varioles are found only in metabasalt with $<12 \% \quad \mathrm{MgO}$ but otherwise the compositions of variolitic lava do not seem to be unusual or distinctive.

\section{Discussion}

The most plausible hypotheses for the formation of varioles are spherulitic crystallisation in a silicate melt or glass (Gregory 1891; Fowler et al. 1987), separation of drops of immiscible silicate melt (Ferguson and Currie 1972; Gelinas et al. 1976) and post-magmatic hydrothermal or metamorphic alteration of basaltic glass (Hanski 1993).

The notion that varioles may have been drops of dacitic or rhyolitic melt, immiscible or otherwise, dispersed in basic lava has received support from the dichotomy in chemical compositions, their near spherical shapes and the postulated preservation of different stages of coalescence. If such droplets were formed prior to surface eruption, one might reasonably expect to find varioles preserved in the outermost rapidly chilled and originally vitreous margins of pillows and possibly deformed and streaked out due to flow. On the contrary, in the Hooggenoeg Complex, varioles are absent along the margins of pillows and they are consistently spherical despite occurring within narrow and contorted flow bands. Both of these observations argue against the formation of varioles as droplets of melt prior to eruption. The varioles must also have post-dated the flowage and mingling of two basaltic magmas that resulted in the banding. This contradicts the suggestion that varioles can be concentrated into the cores of pillows during lava flowage (Arndt and Fowler 2004).

Philpotts (1977) has argued that droplets of immiscible melt frozen while coalescing should exhibit rounded cusps at their contacts. The varioles we have examined do not show this pattern; varioles in contact with each other have sharp, v-shaped cusps. In addition, contiguous varioles preserve their individual internal concentric zonation and radial texture. The outwardly branching crystals of albite observed in the varioles show that they grew from the centre outwards, a pattern that would be entirely unexpected if due to crystallisation within a drop of melt.

The distribution of minor and trace elements between varioles and their host metabasalt does not support their interpretation as coexisting $\mathrm{SiO}_{2}$-rich and Fe-rich silicate melts. $\mathrm{P}_{2} \mathrm{O}_{5}, \mathrm{TiO}_{2}$ and $\mathrm{REE}$ are preferentially partitioned into low-silica immiscible melts (Watson 1976; Philpotts 1982), but their concentrations in the Hooggenoeg varioles and metabasalt are similar. The almost identical total concentrations of REE and similar concentrations of both compatible and incompatible trace elements in varioles and their host metabasalt give no support to the idea that varioles may represent drops of more differentiated melt as suggested by Appel et al. (2009). Nevertheless, there is a 


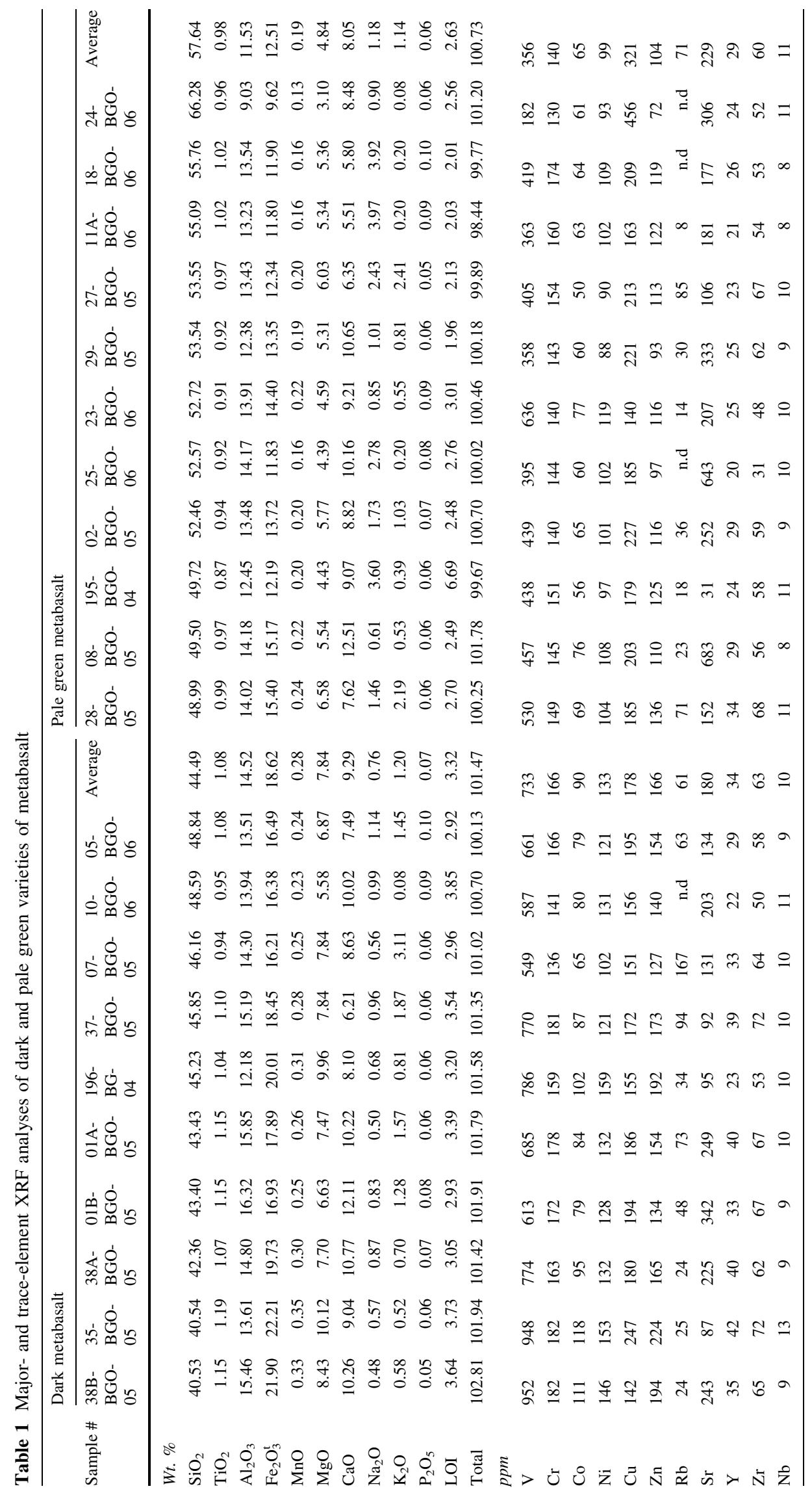


Table 2 Major- and trace-element XRF analyses of isolated varioles

\begin{tabular}{|c|c|c|c|c|c|c|c|}
\hline Sample \# & 02-BGO-06 & 07-BGO-06 & 08-BGO-06 & 26-BGO-06 & 11B-BGO-06 & 33-BGO-05 & Average \\
\hline Wt. \% & a & & a & & & & \\
\hline $\mathrm{SiO}_{2}$ & 58.06 & 60.65 & 62.70 & 64.20 & 65.19 & 67.72 & 63.09 \\
\hline $\mathrm{TiO}_{2}$ & 0.88 & 0.83 & 0.81 & 0.84 & 0.85 & 0.89 & 0.85 \\
\hline $\mathrm{Al}_{2} \mathrm{O}_{3}$ & 11.52 & 16.93 & 10.82 & 12.26 & 14.48 & 12.14 & 13.03 \\
\hline $\mathrm{Fe}_{2} \mathrm{O}_{3}^{\mathrm{t}}$ & 10.14 & 3.63 & 6.00 & 4.89 & 3.32 & 5.34 & 5.55 \\
\hline $\mathrm{MnO}$ & 0.16 & 0.06 & 0.10 & 0.08 & 0.04 & 0.08 & 0.09 \\
\hline $\mathrm{MgO}$ & 2.80 & 0.55 & 1.65 & 1.44 & 0.59 & 1.53 & 1.43 \\
\hline $\mathrm{CaO}$ & 6.75 & 5.26 & 8.70 & 7.22 & 4.48 & 3.26 & 5.95 \\
\hline $\mathrm{Na}_{2} \mathrm{O}$ & 4.83 & 7.27 & 3.70 & 4.25 & 7.99 & 5.32 & 5.56 \\
\hline $\mathrm{K}_{2} \mathrm{O}$ & 0.25 & 1.49 & 0.38 & 0.90 & 0.37 & 0.35 & 0.62 \\
\hline $\mathrm{P}_{2} \mathrm{O}_{5}$ & 0.09 & 0.13 & 0.14 & 0.09 & 0.11 & 0.05 & 0.10 \\
\hline LOI & 4.70 & 1.46 & 4.82 & 3.51 & 1.49 & 1.31 & 2.88 \\
\hline Total & 100.18 & 98.26 & 99.82 & 99.68 & 98.91 & 97.99 & 99.14 \\
\hline \multicolumn{8}{|l|}{ ppm } \\
\hline V & 376 & 81 & 171 & 174 & 82 & 208 & 182 \\
\hline $\mathrm{Cr}$ & 119 & 132 & 139 & 151 & 138 & 176 & 143 \\
\hline Co & 41 & 11 & 35 & 25 & 19 & 31 & 27 \\
\hline $\mathrm{Ni}$ & 111 & 20 & 71 & 53 & 34 & 74 & 61 \\
\hline $\mathrm{Cu}$ & 185 & 158 & 190 & 197 & 181 & 206 & 186 \\
\hline $\mathrm{Zn}$ & 65 & 19 & 50 & 36 & 25 & 49 & 41 \\
\hline $\mathrm{Rb}$ & 5 & 30 & 8 & 18 & 6 & 13 & 13 \\
\hline $\mathrm{Sr}$ & 83 & 173 & 114 & 86 & 90 & 94 & 107 \\
\hline Y & 13 & 22 & 22 & 22 & 18 & 14 & 19 \\
\hline $\mathrm{Zr}$ & 64 & 41 & 50 & 48 & 63 & 57 & 54 \\
\hline $\mathrm{Nb}$ & 6 & 5 & 9 & 7 & 5 & 6 & 6 \\
\hline
\end{tabular}

${ }^{a}$ Samples consisting of impinging varioles from the central parts of pillows

Table 3 ICP-MS analyses of rare earth elements in isolated varioles, their host dark green metabasalts and associated pale green metabasalts

\begin{tabular}{|c|c|c|c|c|c|c|c|c|c|c|}
\hline \multirow[b]{2}{*}{ Sample \# } & \multicolumn{3}{|c|}{ Dark metabasalt } & \multicolumn{3}{|c|}{ Pale metabasalt } & \multicolumn{4}{|l|}{ Varioles } \\
\hline & $\begin{array}{l}\text { 31B-BGO- } \\
06\end{array}$ & $\begin{array}{l}\text { 05-BGO- } \\
06\end{array}$ & $\begin{array}{l}23 \text {-BGO- } \\
06\end{array}$ & $\begin{array}{l}\text { 29-BGO- } \\
05\end{array}$ & $\begin{array}{l}\text { 24-BGO- } \\
06\end{array}$ & $\begin{array}{l}\text { 25-BGO- } \\
06\end{array}$ & $\begin{array}{l}\text { 08-BGO- } \\
06\end{array}$ & $\begin{array}{l}\text { 33-BGO- } \\
05\end{array}$ & $\begin{array}{l}\text { 26-BGO- } \\
06\end{array}$ & $\begin{array}{l}\text { 31A-BGO- } \\
06\end{array}$ \\
\hline \multicolumn{11}{|l|}{ ppm } \\
\hline $\mathrm{La}$ & 2.7 & 3.0 & 3.0 & 2.7 & 2.7 & 3.2 & 3.4 & 2.9 & 3.6 & 4.1 \\
\hline $\mathrm{Ce}$ & 8.5 & 9.0 & 8.5 & 8.1 & 8.0 & 8.7 & 8.7 & 8.2 & 9.4 & 11.6 \\
\hline $\operatorname{Pr}$ & 1.5 & 1.5 & 1.4 & 1.3 & 1.3 & 1.3 & 1.3 & 1.3 & 1.4 & 1.7 \\
\hline $\mathrm{Nd}$ & 7.9 & 7.9 & 7.3 & 7.0 & 6.8 & 7.1 & 6.9 & 6.6 & 7.1 & 8.6 \\
\hline $\mathrm{Sm}$ & 2.8 & 2.7 & 2.6 & 2.4 & 2.4 & 2.4 & 2.2 & 2.1 & 2.2 & 2.7 \\
\hline $\mathrm{Eu}$ & 1.0 & 1.1 & 1.1 & 1.0 & 0.8 & 0.9 & 0.7 & 0.7 & 0.8 & 0.9 \\
\hline $\mathrm{Tb}$ & 0.6 & 0.6 & 0.6 & 0.5 & 0.5 & 0.5 & 0.5 & 0.4 & 0.4 & 0.5 \\
\hline Dy & 3.7 & 4.0 & 3.7 & 3.4 & 3.4 & 3.3 & 2.9 & 2.6 & 2.7 & 2.9 \\
\hline Ho & 0.8 & 0.9 & 0.8 & 0.7 & 0.7 & 0.7 & 0.6 & 0.5 & 0.6 & 0.6 \\
\hline $\mathrm{Er}$ & 2.3 & 2.5 & 2.3 & 2.1 & 2.1 & 2.1 & 1.8 & 1.5 & 1.7 & 1.6 \\
\hline $\mathrm{Tm}$ & 0.3 & 0.4 & 0.3 & 0.3 & 0.3 & 0.3 & 0.3 & 0.2 & 0.3 & 0.2 \\
\hline $\mathrm{Yb}$ & 2.3 & 2.5 & 2.4 & 2.1 & 2.1 & 2.1 & 1.9 & 1.5 & 1.8 & 1.4 \\
\hline $\mathrm{Lu}$ & 0.3 & 0.4 & 0.4 & 0.3 & 0.3 & 0.3 & 0.3 & 0.2 & 0.3 & 0.2 \\
\hline
\end{tabular}



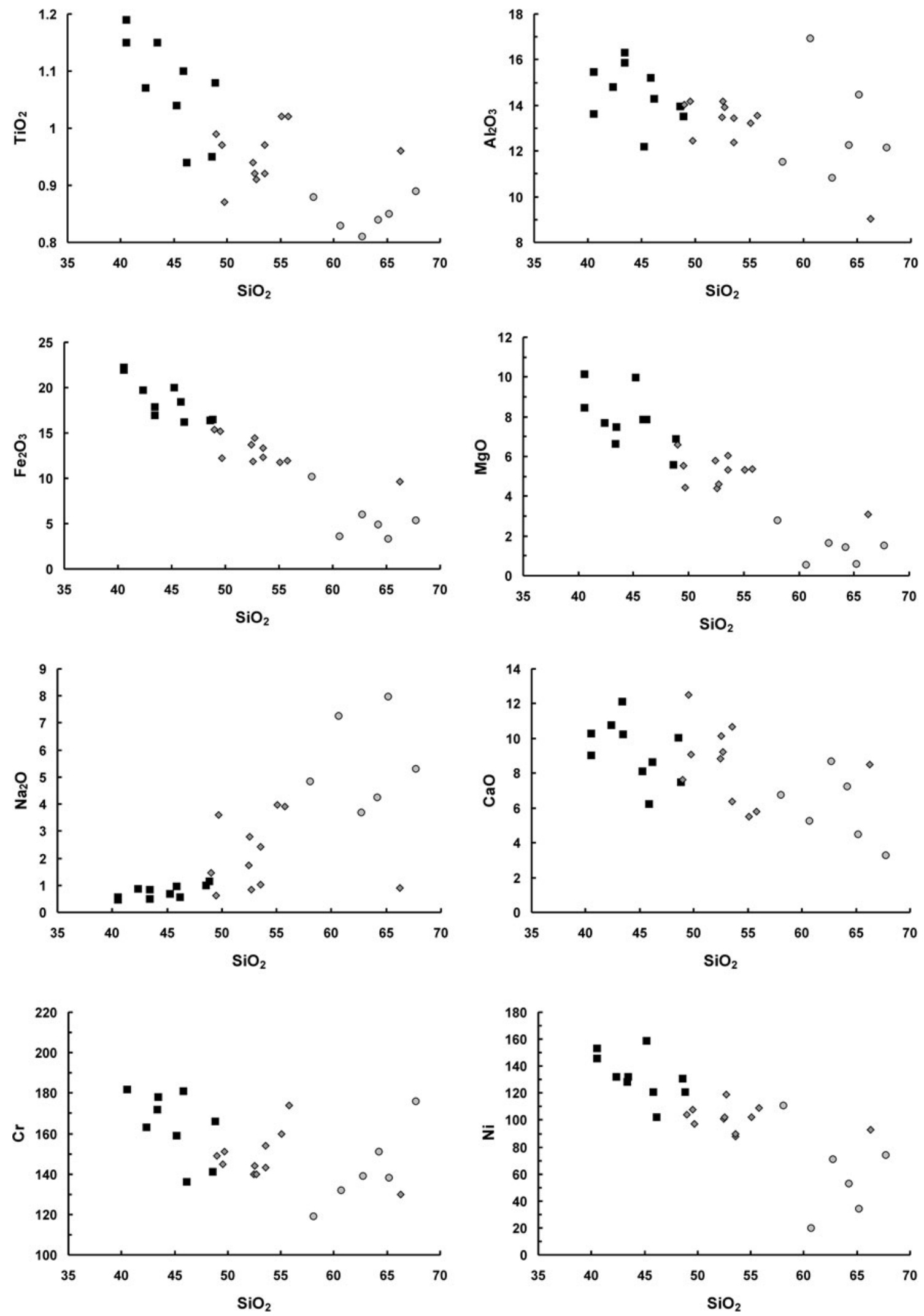

Fig. 9 Harker diagrams for selected elements in varioles (circles), their host dark green metabasalt (dark squares) and the associated pale green metabasalt (diamonds) 
Fig. 10 REEs in varioles (grey circles), host dark green metabasalt (black squares) and pale green metabasalt ( grey diamonds) normalised to the concentrations in chondrites as compiled by Boynton (1984)

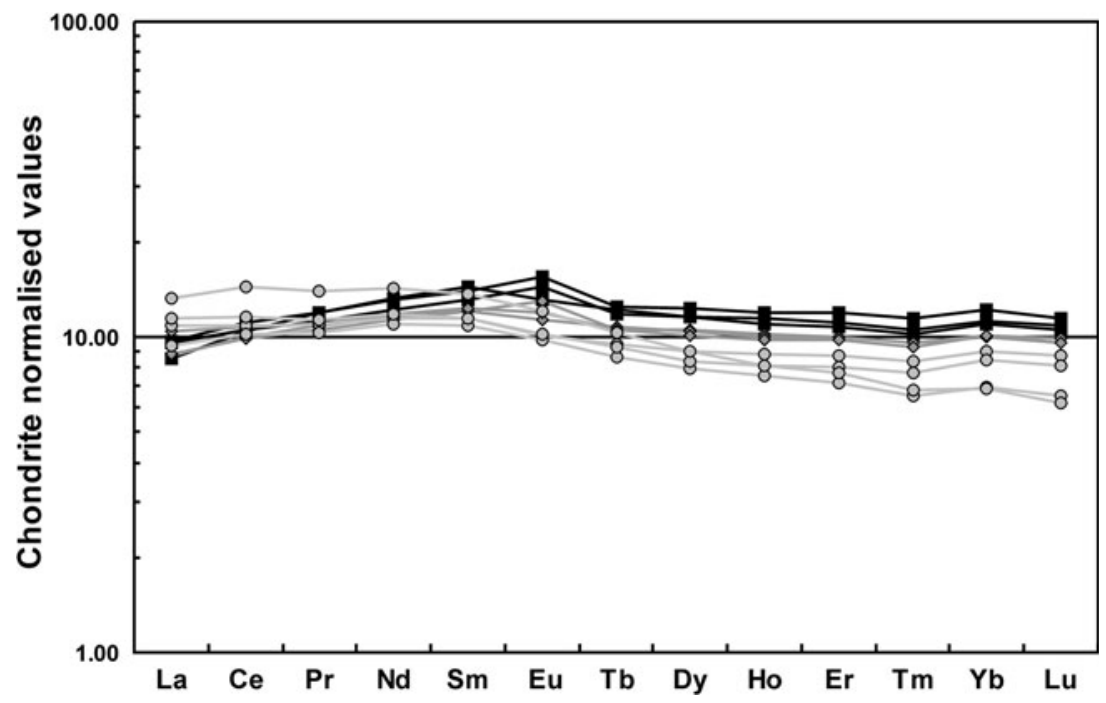

clear dichotomy in the major-element compositions of varioles and the host metabasalt that requires explanation. This is in part a consequence of the low-temperature hydrothermal alteration of the rocks. This involved chloritisation of primary volcanic glass and any mafic minerals present in the groundmass between plagioclase spherulites, resulting in the release of $\mathrm{SiO}_{2}, \mathrm{CaO}$ and alkalies as well as enrichment in $\mathrm{FeO}$ and $\mathrm{MgO}$. On the other hand, transformation of the original spherulitic basic plagioclase into albite (and alkali feldspar) required the addition of $\mathrm{SiO}_{2}$ and alkalies, if $\mathrm{Al}_{2} \mathrm{O}_{3}$ was immobile. Thus, alteration may well have involved a complementary chemical exchange between contrasting parts of the original lavas. The radial orientation and dendritic habit of the albite and $\mathrm{K}-\mathrm{Na}$ feldspar in the varioles is inconsistent with crystallisation of discrete drops of melt but is strong evidence that they are altered spherulites that presumably consisted of calcic plagioclase prior to hydrothermal alteration and subsequent low-grade metamorphism.

Spherulites crystallise in severely undercooled lava (Lofgren 1974), characterised by a very low rate of nucleation but a comparatively high supersaturation and rate of crystal growth. They nucleate more readily on interfaces than homogenously within an undercooled melt or glass (e.g. Barbieri et al. 2005) and at least some Hooggenoeg varioles appear to have nucleated on small vesicles. This is in accord with observations of the heterogeneous nucleation of spherulites on gas bubbles in experiments with lithium disilicate melts (Davis and Ihinger 1998). The general scarcity of vesicles in the Hooggenoeg lavas is attributed to eruption beneath more than $2 \mathrm{~km}$ of water (Furnes et al. in press). Varioles also appear to have nucleated along the flat undersides of small cavities in pillows resulting from drainage of lava. These cavities were presumably gas filled, at least initially, and spherulites could nucleate on their floors and grow into the underlying fluid melt, but apparently not into the overlying cooler and already solidified carapaces.

The wide bands of impinging varioles developed in flow-banded lava along internal contacts with dark cores, inferred to have originated by the later filling of drained and hollow pillows by hot basalt lava (Robins et al. 2010b), are suggested to have nucleated and grown on the inner sides of drained pillows during reheating of the pillow margins to a temperature high enough for spherulitic growth of feldspar in the original obsidian (Lewis et al. 1979) when they were refilled with lava.

The plagioclase spherulites grew initially from fluid basalt and possibly continued to crystallise in glass when the temperature fell beneath the glass transition. The textures suggest that plagioclase spherulites initially grew from melt unimpeded by other minerals, while later on, and at lower temperature, they continued to grow between skeletal crystals of pyroxene. In some instances, spherulitic crystallisation of plagioclase appears to have resulted in the exsolution of gases dissolved in the basaltic melt and the growth of tiny radial vesicles, akin to the pipe vesicles commonly found within the crusts of basaltic pillows (Philpotts and Lewis 1987). Some bubbles of gas were eventually trapped on the surfaces of spherulites, presumably due to the increasing viscosity of the surrounding cooled melt, and continued growth of the spherulite enveloped them. We speculate that the growth of the finergrained margins of varioles may have taken place at temperatures below the glass transition. We suggest that this is a plausible explanation of the relationship observed by Hanski (1993) between varioles and early fractures, but we reject his hypothesis of the development of varioles during post-magmatic hydrothermal or metamorphic alteration of glass. Bands of impinging varioles orientated across the 
long axes of some elongated pillows near the top of the Hooggenoeg Complex (Fig. 8) are also possibly the result of growth from very early cooling fractures into the adjacent glass.

Banding in the variolitic pillows is inferred to be a consequence of the stretching and folding of a dispersion of two different types of basalt lava during the flow of lava through tubular pillows. Plagioclase spherulites crystallised in only one of these basalts, the other being characterised by pyroxene spherulites. This is inferred to be a consequence of original compositional differences between the lavas. Intimate mingling of the two basalts during flow must have rapidly equalised their temperatures, and they subsequently must have experienced an identical thermal history. The process of mingling could, however, have led to an additional supercooling of the initially hotter lava, inferred to be the dark, variolitic variety of metabasalt.

Both types of basalt in the Hooggeneog flow-banded pillows are devoid of pseudomorphed phenocrysts. Fowler et al. (1987) and Arndt and Fowler (2004) suggest that variolitic lavas may have been erupted in a superheated condition, due to rapid adiabatic ascent, eliminating most crystal nuclei and thereby promoting supersaturation and spherulitic crystallisation during subsequent cooling. We have noted above that variolitic lavas in the Hooggenoeg Formation are unexceptional in both composition and mode of occurrence, and it seems unavoidable that some other factor, such as a dearth of nucleation sites due to previous superheating, was instrumental in the formation of such exceptionally large plagioclase spherulites. Furnes et al. (in press) note that basaltic pillow lavas in the Hooggenoeg Complex contain less than 5\% vesicles, suggesting eruption at water depths of more than $2,000 \mathrm{~m}$. In general, vesicular pillows occur in the stratigraphically lowest part of the complex while non- to very sparsely vesicular and variolitic pillows are found near the top, suggesting eruption in a subsiding basin. Eruption in deep water and retention of more abundant volatiles in solution in the melt phase may have allowed spherulitic crystallisation of plagioclase to take place at a lower degree of undercooling and at a higher growth rate than in submarine basaltic pillowed flows today. This may be the reason for the occurrence of varioles in the cores of pillows, where the rate of cooling and hence the degree of undercooling of the lava must have been lower, rather than being restricted to their tachylitic margins, as is generally the case in young pillow lavas (Kirkpatrick 1979; Natland 1980; Alt et al. 1993).

Hanski (1993) asks where varioles, if they are igneous in origin, can be found in recent, or at least fresh, basalt. In fresh rocks, large plagioclase spherulites would not necessarily be as conspicuous as in they are in hydrothermally altered and metamorphosed lava, but Harker (1954) lists several examples of variolitic basaltic dykes from the British Palaeogene volcanic district, including a remarkable occurrence on the Isle of Skye that contains plagioclase spherulites as much as $7 \mathrm{~cm}$ in diameter (see Harker 1954, Fig. 64b).

\section{Conclusions}

Field, textural and geochemical observations all support the interpretation of the conspicuous leucocratic varioles in the Archaean subaqueous lavas within the Hooggenoeg Complex of the Barberton Greenstone Belt as exceptionally large plagioclase spherulites. Their spherical shape, the existence of sharp cusps between and concentric zones within impinging varioles, the internal radial orientation of pseudomorphed crystal fibres and the concentrations of relatively immobile elements such as $\mathrm{P}_{2} \mathrm{O}_{5}, \mathrm{TiO}_{2}, \mathrm{Cr}, \mathrm{Zr}$ and REE are not compatible with their being drops of acid melt, immiscible or otherwise.

The plagioclase spherulites crystallised from highly undercooled, aphyric basalt melt or glass in which crystal nucleation was severely restricted. Some spherulites nucleated on the surfaces of small and sparse vesicles, while others grew from the undersides of drainage cavities in pillows or along early cooling fractures. The growth of some spherulites resulted in the formation of tiny pipe vesicles. Vesicles that were eventually trapped on the surfaces of spherulites, due to an increase in the viscosity of the melt as the temperature decreased, were enveloped by continued growth of a finer-grained rim.

The growth of the plagioclase spherulites appears initially to have been uninhibited by other minerals, but in some instances skeletal pyroxene crystals that started to grow later in the surrounding melt are enveloped by the margins of the spherulites. We suggest that the very fine-grained margins of the spherulites may have crystallised at a temperature below that of the glass transition.

Variolitic metabasalts in the Hooggenoeg Complex apparently have unexceptional major-element compositions and, as suggested by Arndt and Fowler (2004), the unusually large varioles may reflect previous superheating due to rapid ascent of the basaltic magma to the surface and the consequent elimination of crystal nuclei. However, relatively high concentrations of magmatic volatiles and their retention in the basaltic melt due to eruption beneath $>2 \mathrm{~km}$ of water (Furnes et al. in press) may have permitted spherulitic growth to take place at a lower degree of supersaturation (and hence a lower rate of cooling) and at an enhanced rate than in younger submarine flows, resulting in the unusually abundant and large spherulites that characterise some of the Hooggenoeg lavas. 
Acknowledgments The authors thank the Mpumalanga Parks Board for their permission to collect samples within the Songimvelo Nature Reserve. We are extremely grateful to Fred Daniel of the Nkomazi Wilderness Resort for his generous hospitality. This is AEON contribution no. 89 .

Open Access This article is distributed under the terms of the Creative Commons Attribution Noncommercial License which permits any noncommercial use, distribution, and reproduction in any medium, provided the original author(s) and source are credited.

\section{References}

Alt JC, Kinoshita H, Stokking LB, et al. (1993) In: Proceedings of the ocean drilling program. Initial reports 148, College Station, p 352

Appel PWU, Polat A, Frei R (2009) Dacitic ocelli in mafic lavas, 3.8-3.7 Ga Isua Greenstone Belt, West Greenland: geochemical evidence for partial melting of oceanic crust and magma mixing. Chem Geol 258:105-124

Arndt N, Fowler AD (2004) Textures in komatiites and variolitic basalts. In: Erikson $\mathrm{K}$ et al (eds) The precambrian earth: tempos and events. Elsevier, Amsterdam, pp 298-311

Boynton WV (1984) Cosmochemistry of the rare earth elements: meteorite studies. In: Hendersen P (ed) Rare earth geochemistry. Elsevier, Amsterdam, pp 63-114

Dann JC, Grove TL (2007) Volcanology of the Barberton Greenstone Belt, South Africa: inflation and evolution of flow fields. Dev Precamb Geol 15:527-570

Davis MJ, Ihinger PD (1998) Heterogeneous crystal nucleation on bubbles in silicate melt. Am Miner 83:1008-1015

de Wit MJ, Furnes H, Robins B (in press). Geology and stratigraphic architecture of the Onverwacht Suite, Barberton Mountain Land, South Africa. Precamb Res

Ferguson J, Currie KL (1972) Silicate immiscibility in the ancient "Basalts" of the Barberton Mountain Land, Transvaal. Nat Phys Sci 235:86-89

Fowler AD, Jensen LS, Peloquin SA (1987) Varioles in Archean basalts; products of spherulitic crystallization. Can Miner 25:275-289

Fowler AD, Berger B, Shore M, Jones MI, Ropchan J (2002) Supercooled rocks: development and significance of varioles, spherulites, dendrites and spinifex in Archean volcanic rocks, Abitibi Greenstone Belt, Canada. Precamb Res 115:311-328

Furnes H, de Wit M J, Robins B, Sandstå NR (in press) Volcanic evolution of the upper Onverwacht Suite, Barberton Mountain Land, South Africa. Precamb Res

Gelinas L, Brooks C, Trzcienski WE (1976) Archean variolitesquenched immiscible liquids. Can J Earth Sci 13:210-230

Govindaraju K (1994) Compilation of working values and sample description for 383 geostandards. Geostand Newslett Spec Iss $18: 1-158$
Gregory JW (1891) The variolitic diabases of the Fichtelgebirge. Quart J Geol Soc 47:45-62

Hanski EJ (1993) Globular ferropicritic rocks at Pechenga, Kola Peninsula (Russia): liquid immiscibility versus alteration. Lithos 29:197-216

Harker A (1954) Petrology for students: an introduction to the study of rocks under the microscope, 8th edn. University Press, Cambridge

Kerr AC, Tarney J, Marriner GF, Klaver GT, Saunders AD, Thirlwall MF (1996) The geochemistry and petrogenesis of the lateCretaceous picrites and basalts of Curacao, Netherland Antilles: a remnant of an oceanic plateau. Contrib Miner Petrol 124:29-43

Kirkpatrick RJ (1979) Processes of crystallisation in pillow basalts. Hole 396B, DSDP Leg 46. In: Dmitriev L, Heirtzler J (eds) Initial reports of the deep sea drilling project, vol 46, pp 271-282

Lewis MH, Metcalf-Johansen J, Bell PS (1979) Crystallization mechanisms in glass-ceramics. J Am Ceram Soc 62:278-288

Lofgren G (1974) An experimental study of plagioclase crystal morphology: isothermal crystallization. Am J Sci 274:243-273

Lowe DR, Byerly GR (1999) Stratigraphy of the west-central part of the Barberton Greenstone Belt, South Africa. Geol Soc Am Spec Pap 329:1-36

Lowe DR, Byerly GR (2007) An overview of the geology of the Barberton Greenstone Belt and vicinity: implications for early crustal development. Dev Precamb Geol 15:481-526

Natland JH (1980) Crystal morphologies in basalts dredged and drilled from the East Pacific Rise near $9^{\circ} \mathrm{N}$ and the Siqueiros Fracture Zone. In: Rosendahl BR, Heikinian R et al (eds) Initial reports of the deep sea drilling project, vol 54, pp 605-633

Philpotts AR (1977) Archean variolites-quenched immiscible liquids? Discussion. Can J Earth Sci 14:139-144

Philpotts AR (1982) Compositions of immiscible liquids in volcanic rocks. Contrib Miner Petrol 80:201-218

Philpotts AR, Lewis CL (1987) Pipe vesicles-an alternative model for their origin. Geology 15:971-974

Robins B, Sandstå NR, Furnes H, de Wit M (2010a) Flow banding in basaltic pillow lavas from the Early Archean Hooggenoeg Formation, Barberton Greenstone Belt, South Africa. Bull Volcanol 72:579-592

Robins B, Sandstå NR, Furnes H, de Wit M (2010b) Evidence for refilling of previously emptied basaltic pillows in the Hooggenoeg Complex, Barberton Greenstone Belt. Geol Mag. doi: $10.1017 /$ S0016756810000853

Shipboard Scientific Party (2001) Basement drilling of the Ontong Java Plateau. ODP Prelim Rep 192

Upadhyay HD (1982) Ordovician komatiites and associated boninitetype magnesian lavas from Betts Cove, Newfoundland. In: Arndt NT, Nisbet EG (eds) Komatiites. George Allen \& Unwin, London, pp 187-198

Viljoen MJ, Viljoen RP (1969) The geology and geochemistry of the Lower Ultramafic Unit of the Onverwacht Group and a proposed new class of igneous rocks. Geol Soc S Africa Spec Pub 2:55-85

Watson EB (1976) Two-liquid partition coefficients: experimental data and geochemical implications. Contrib Miner Petrol 56:119-134 